\title{
Development as Zombieconomics in the Age of Neo-Liberalism
}

Ben Fine, SOAS, University of London

Paper for the 35th anniversary conference for the Center for International Development Issues, CIDIN, Radboud University, Nijmegen, Netherlands, September 2008

\section{$1 \underline{\text { Introduction }}$}

This paper approaches the prospects for development studies by examining its shifting relationship to development economics. The latter's own history is characterised in terms of its capture by economics imperialism over the period of the Washington Consensus and Post Washington Consensus in sections 2 and 3. The corresponding shift from the old to the new (and "newer") development economics is associated with an increasing influence over development studies, especially through the growing role of the World Bank as knowledge bank. But, as argued in section 4, the dull and universal compulsion of what is dubbed zombieconomics is open to challenge from development studies in light of its multi-, even inter-, disciplinarity. Further, as suggested in section 5, the current intellectual environment of dual retreat from the extremes of both post-modernism and neo-liberalism, renewal of interest in the systemic nature of contemporary capitalism, and the increasing need to respond to the dysfunctions associated with financialisation, offer development studies the most favourable circumstances in which both to prosper and to outflank the designs of economics imperialism. The final section offers a heavily abbreviated illustration by reference to the evolving political economy of South Africa.

\section{From Economics to Economics Imperialism ${ }^{1}$}

Whilst the history of development studies has been written a number of times and from a number of perspectives, the same is less true of development economics. In two respects, at least, this is remarkable for, first, development economics has changed beyond recognition within my own lifetime as an economist (and I am not so old). In addition, second, in violation of the law that history is written by the victors, most reflections on the evolution of development economics have originated from the vanquished, as it were, those who regret the direction it has taken and who wish to restore the methods, substance and pre-occupations of what has gone before and been discarded. In short, there is a new (and I might also refer to a newer and newest) development economics that is distinctive from and, in general, ignorant of the old or classic development economics as part and parcel of casual neglect of its own intellectual precursors.

These are matters to which I will soon return but to do so it is first necessary to locate development economics within the broader scope of the discipline of economics itself for the two have gone from occupying parallel universes to being more or less synonymous with one another. It is also important to locate (development) economics in relation to other disciplines. And, unlike history itself, this can be done with the benefit of hindsight and by starting with the here and now and travelling backwards to reveal how we got where we are - although explanation for this is more challenging than description. 
First and foremost, as a discipline, mainstream economics is increasingly subject to an esoteric and intellectually bankrupt technicism that is absolutely intolerant of alternatives and only allows for them to survive on its margins. The technical apparatus that this involves, utility and production functions, are wellknown to students of economics at every level of the discipline, as is the methodological focus of relying upon optimising individuals in single-minded pursuit of self-interest, embedded within formal mathematical models centred on (deviations from) efficiency and equilibrium, and reputedly tested against the evidence statistically. Despite its considerable and longstanding methodological and theoretical fragilities, especially from the perspectives of other social sciences, there is no sign that this situation of mono-economic dominance within the discipline is liable to change as a result of internally or externally generated critique. Indeed, mainstream economics continues to strengthen its stranglehold through research, publications and training with Americanisation to the fore. Insofar as there are disputes within economics, it is on the basis of very narrow differences across a much wider acceptance of core methods and techniques.

Second, paradoxically then, the influence of economics on other social sciences is currently stronger than at any other time in the post-war period. This is a consequence of a new and virulent form of "economics imperialism" that takes neoliberalism as its point of departure. Emphasising that markets work well in general, it also accepts that the economy is subject to market imperfections, to which evolved institutional (or non-market) outcomes are the response (and which may themselves be subject to imperfection). But, in contrast to neo-liberalism, the mainstream can now claim that it takes history, culture, institutions into account seriously as joint, potentially favourable, determinants alongside the market. And this opens up the traditional subject matter of other social sciences as economists claim to be taking their concerns seriously albeit on their own methodological terms.

This involves, on the one hand, an extraordinary reductionism of the social to informational or market imperfections and pursuit of self-interest while, on the other, considerable scope for inscribing (bringing back in) the social by plunder of concepts and insights from other social sciences (ranging from trust and customs to institutions, etc). But, within mainstream economics, despite the absolute dominance of methodological individualism in its current form and the widespread belief in the harmonious, if at times flawed, properties of free market capitalism, there is no unified ideology comparable to post-war Keynesianism (or, indeed, mid-nineteenthcentury free trade Ricardianism). Rather, orthodoxy is more a matter of adhering to technique and adopting a certain approach in resolving theoretical and empirical problems. As a result, both in popular and academic discourse, the diffuse nature of the new orthodoxy - its postures are contingent on the incidence and nature of market (and institutional) imperfections - makes challenges to it more difficult and less influential (unlike potential for unifying opposition to the challenge of neo-liberalism that is readily perceived as more or less narrow-minded dogma).

Third, in the realm of methodology, the social sciences remain generally hostile to the methods and postures of mainstream economics, when they are explicitly confronted rather than informally incorporated. Nevertheless, rational choice adherents have made much headway in sociology, political science, history, 
and elsewhere. As a result, the depth, extent and nature of the influence of economics imperialism by topic and discipline are diverse, not least in light of continuing traditions, content and dynamics of the other social sciences. In addition, the openness of the other social sciences to economic arguments also reflects the current intellectual retreat across the social sciences from the excesses of both postmodernism and neo-liberalism, although the latter's presence and continuing influence occasionally remain strong. Thus, the current intellectual environment is one in which the social sciences are more open to economic arguments in seeking to address the nature of contemporary capitalism. This also opens the way for economics imperialism. On the other hand, there is less appeal as far as other disciplines are concerned where the social and the systemic are genuinely taken as starting points, as in attention to relations, structures, conflict, power and critical attention to the meaning of concepts deployed, both to scholars and the objects of their scholarship (issues entirely unknown to mainstream economics and much political economy as well).

Fourth, over the post-war period, economics began by being dominated by an uneasy analytical compromise between Keynesianism (and a concern with systemic behaviour in the limited form of orthodox macroeconomics) and general equilibrium theory and microeconomics (in which deviation from conditions for perfect competition might warrant intervention by a benevolent state). This compromise was rudely shattered by the collapse of the post-war boom and the emergence of a particularly virulent form of monetarism (the New Classical Economics) in which it was presumed that the state was at best ineffective and at worst a source of inefficiency. This all went hand in hand with strengthening the role of microeconomics (and methodological individualism) both within the discipline and in pushing the cruder and earlier forms of economics imperialism in which the noneconomic is understood not as the result of market (and institutional) imperfections but as the functioning of the market by other means as in public choice, property rights or human capital theory.

During the Keynesian period, mainstream economics had retained some idea of the limitations on the scope of application of both its macro and micro principles, within economics itself let alone in extension to other disciplines. This left some considerable scope and respect for applied economics to prosper with empirically rooted inductive analysis to the fore across a range of topics that seemed to lie outside the domain of mainstream economic theory. In today's world, such analysis has been displaced by new theoretical fields, and empirical methods, as in the new institutional economics, the new growth theory, the new economic geography, and the new welfare economics, in which market and institutional imperfections are now used to substitute universal theoretical principles for empirical investigation other than through statistical testing.

In short, the new form of economics imperialism and the economic theory on which it is based, with emphasis on market and institutional imperfections, can be caricatured as "zombieconomics", Fine (2008a). This is because is it both alive and dead at the same time. It is alive in the sense of not only aggressively and crudely, if not savagely, occupying its own territory and subject matter to the exclusion and absorption of competing paradigms but also through its increasing appetite for the flesh of other disciplines that it both infects and converts to its own nature with only 
limited traces remaining of what has been destroyed. By the same token, it is intellectually dead, having nothing new to offer other than parasitic extension of its principles to new applications.

\section{From Pre- to Post-Washington Consensus}

This brief overview of the history of the discipline in general does itself offer insights into the evolution of development economics in particular. For sake of convenience, I divide the evolution of development economics into three periods. The last two are familiar and recent enough to be instantly recognised and also to have been, in a limited way, heavily debated. They are those associated with the Washington Consensus and the Post Washington Consensus, PWC. Their correspondence with broader disciplinary changes are more or less immediate. As a product of the 1980s, the Washington Consensus is a reflection of the rise of neoliberalism and the analytical pre-occupation with the pursuit of self-interest, most obviously in terms of the notion of rent-seeking and, subsequently, corruption and governance especially in the wake of the problems posed by the transition economies. Development economics for the Washington Consensus is simply the application of the crude, non-market as if market, economics imperialism to the field, and gave rise to what has since been termed the new development economics in which formalism also played an increasing role. By the same token, the PWC is based on what I like to term the newer development economics since it applies the (market and institutional imperfection) information-theoretic approach to development with Stiglitz to the fore.

With the shift over the past decade from one Consensus to another, it is natural to understand the old development economics as constituting part of a preWashington Consensus. This too can be pinpointed in terms of its location within the earlier character of economics as a discipline. As a specific field, it is generally recognised to have emerged after the second world war as a response to decolonisation. As a result, it is not surprising that it should stand apart in method and content from the theoretical designs of standard micro and macro, as did other applied and historical fields. The old development economics was concerned with how economic rationality could become adopted within developing economies (thereby accepting that all behaviour is not necessarily rational) and how broad economic and social transformation could be brought about, especially through the agency of the state. Toye (1993, p. 30-31) describes the old development economics in the following terms:

The original theory of socioeconomic development that accompanied the post1945 decolonization of Asia and Africa rested on the idea of modern society as the goal of development. Modern society supposedly had typical social patterns of demography, urbanization and literacy; typical economic patterns of production and consumption, investment, trade and government finance; and typical psychological attributes of rationality, ascriptive identity and achievement motivation. The process of development consisted, on this theory, of moving from traditional society, which was taken as the polar opposite of the modern type, through a series of stages of development derived essentially from the history of Europe, North America and Japan - to modernity, that is, approximately the United States of the 1950s. 
Thus, the old development economics was concerned with broad socio-economic processes and structural change as opposed to a theory of choice based on economic rationality. By the same token, the old development economics was inductive rather than deductive, seeking out empirical regularities in the transition from traditional to transitional society. And, in conformity to the hegemonic Keynesianism of the time, the old development economics laid considerable emphasis on the role of the state as agent of change (as opposed to focusing on the optimising behaviour of a representative individual). Such features of the old development economics are in part brought out by a commentary on Simon Kuznets, Nobel prize winner for economics and leading empiricist in the study of economic history and development. For Huff et al (2001, p. 719):

Modern economic growth, Kuznets (1971, p. 346) points out, requires a modern nation state to serve as a clearing house for institutional innovations and to possess the ability to act as "an agency for resolution of conflicts among group interests; and as a major entrepreneur for the socially required infrastructure".

Such postures could not sit comfortably within the standard analysis of mainstream neo-classical economics.

Significantly, then, the rise of the old development economics had a close connection to economic history in subject matter and, especially, US personnel reflecting their location within economics departments and the continuing presence of those trained in the institutional tradition. This is most apparent in the work of possibly the most prominent of economic historians at the time, W. W. Rostow. His Stages of Economic Growth: A Non-Communist Manifesto, emphasis added, carried a message to the world that could not be clearer in the wake of the launch of the Sputnik in 1957 and the perceived threat of Soviet economic and technological catchup. Whilst Rostow's ideological credentials could not have been stronger in support of US hegemony, and his volume was to go through three editions and sell three hundred thousand copies, his own stance on economic history was not supportive of the single-minded theory and numbers characteristic of the emerging cliometric school. His schema for development followed a stylised induction of stages of economic growth from the experience of the developed countries. Whilst in part relying on standard growth theory, for Rostow, the ultimate causes of such growth are situated in a framework of modernisation, of breaking up of traditional societies and, correspondingly, of major shifts in political, cultural and social variables that are not reducible to the economic.

This is a consequence of the established style of economic history to which Rostow adhered, but it also reflects a keen commitment to distance his approach from the "economic reductionism" that he attaches to Marxism. Indeed, his book's last chapter is devoted to a critique of Marxism for its economic reductionism (making up $15 \%$ or so of the main body of the text). ${ }^{2}$ The (mis)representation of Marx should not be taken too seriously except as a fascinating ideological text, reflecting (lack of) scholarly values of the time, but the nature of his construct of Marxism is instructive, Rostow (1991, p. 149): 
The first and most fundamental difference between the two analyses lies in the view taken of human motivation. Marx's system is, like classical economics, a set of more or less sophisticated logical deductions from the notion of profit maximization.

Ironically, this is a better description of the economics imperialism of the present day. For Rostow, by contrast:

In the stages-of-growth sequence man is viewed as a more complex unit. He seeks, not merely economic advantage, but also power, leisure, adventure, continuity of experience and security; he is concerned with his family, the familiar values of his regional and national culture, and a bit of fun down at the local ... In short, net human behaviour is seen not as an act of maximization, but as an act of balancing alternative and often conflicting human objectives in the face of the range of choices men perceive to be open to them.

In short, from its own perspective, Rostow provides a manifesto of sorts more against neoclassical economics than Marxism by seeking to retain the notion of a more rounded individual. His antipathy to the idea that history can be reduced to the optimising individual could not be plainer, Rostow (1957, p. 514):

The theorist has generally been uneasy if not awkward if forced to work outside Marshallian short-period assumptions; the historian - like the human beings he writes about - cannot avoid working in a world of changing tastes and institutions, changing population, technology, and capacity.

In short, the old development economics carved a place for itself, like much applied economics more generally, outside the domain of both microeconomics and macroeconomics. In part, this reflected an acceptance that development was to be construed as something more than the economic as traditionally conceived, with a corresponding deference to the limited applicability of depending exclusively on "rationality" and needing to incorporate the insights and methods of the other social sciences. This all changed with the rise of the new development economics at the time of the collapse of the post-war boom and the rise to prominence of neo-liberal ideology. Heavily promoted by the IMF/World Bank inspired Washington Consensus, the new development economics emphasised the virtues of the market and the vices of the state in promoting economic development. But it did much more than this by incorporating development economics into the mainstream, with little or scant regard for the significance of non-economic factors (except as impediments to development). As Agénor and Montiel (1996, pp. 11-12) were to put it at a later stage:

We do not believe that economic agents in developing countries behave differently from those in industrial economies, in ways that are inconsistent with the rational optimising principle of neoclassical microeconomics; rather, we believe that they behave similarly to their industrial counterparts, but operate in a different environment.

In other words, economic principles are universal; only the environment in which they prevail is subject to variation. In this way, an establishment-driven challenge was 
made to both method and content of the old development economics. By driving to the extreme of neo-liberalism in ideology, policy, and scholarship, it provided the basis for a mild reaction against the idea that markets work perfectly whilst allowing those universal principles to be uncritically taken for granted.

Most revealing in this respect is Rodrik's (2007, p. 3) self-refection in a recently published collection of essays, bearing in mind that Rodrik is seen, like Stiglitz for example, as a fierce opponent of neo-liberalism and on the progressive side of the discipline of economics:

First, this book is strictly grounded in neoclassical economic analysis. At the core of neoclassical economics lies the following methodological predisposition: social phenomena can best be understood by considering them to be an aggregation of purposeful behaviour by individuals - in their roles as consumer, producer, investor, politician, and so on - interacting with each other and acting under the constraints that their environment imposes. This I find to be not just a powerful discipline for organizing our thoughts on economic affairs, but the only sensible way of thinking about them. If I often depart from the consensus that "mainstream" economists have reached in matters of development policy, this has less to do with different modes of analysis than with different readings of the evidence and with different evaluations of the "political economy" of developing nations. The economics that the graduate student picks up in the seminar room - abstract as it is and riddled with a variety of market failures - admits an almost unlimited range of policy recommendations, depending on the specific assumptions the analyst is prepared to make. As I will argue in the chapters to come, the tendency of many economists to offer advice based on simple rules of thumb regardless of context (privatize this, liberalize that), is a derogation rather than a proper application of neoclassical economic principles.

This, appropriately interpreted and rephrased, is a manifesto for zombieconomics in general and its dominance over development studies in particular. ${ }^{3}$

In this light, the "newer" development economics does not fundamentally break with the methodology of the new (nor restore the old despite frequent claims to the contrary) even though it is more state-friendly and emphasises the significance of market imperfections. Rather, on the continuing basis of methodological individualism, it seeks to address (lack of) development in terms of market and institutional imperfections. Indeed, development becomes an ideal application for economics imperialism, with formal models of economic and social change and structure being subject to econometric testing.

The result has been to collapse the distinctions between economics, economic history and development studies. In principle, this is no bad thing. It is essential that all three be studied together as development is irreducibly both economic and historical. But, in the hands of the newer development economists, both development and history provide the raw materials by which to provide narrative for the universal methodology of mainstream economics and data by which to test hypotheses. As already indicated, this can come in pure form of continuing to rely exclusively upon imperfectly informed and institutionalised but optimising individuals. One leading 
example is provided by Krugman (1992) whose mathematical models involving increasing returns to scale are perceived by himself to have rescued the old development economics from its technical deficiencies and lack of persuasion. That the classics might have rejected such methods rather than being incapable of them does not appear to occur to him. But this does serve a warning of the extent to which the newer economics imperialism both appropriates and distorts the content of what was once standard but is now perceived to be heterodox. ${ }^{4}$

Significantly, Krugman deploys the same principles and methods to appropriate economic geography, explaining core and periphery relations and uneven development without reference at all to the role of the state let alone policymaking. ${ }^{5}$ This is illustrative of the more general process of subsequently bringing back in on a selective basis what was first left out in establishing the technical apparatus of the mainstream. It is equally to be found in the new growth theory, the new institutional economics and so on. But it also goes hand in hand with marrying such pure use of the technical apparatus with other, more or less, arbitrary elements of the "irrational", accepting for example that individuals may have other motives or be bound by exogenously given institutions. These range from freakonomics to neuroeconomics but also include the new economic sociology which more seriously and critically takes the technical apparatus as point of departure. Typical in so far as this is possible in an environment of such idiosyncrasy is the work of Bates et al (1998) in their Analytic Narratives. On the analytic side, there is little novelty other than the scope of the approach in covering both history and development, p. 8:

Institutions ... induce choices that are regularized because they are made in equilibrium ... Behavior becomes stable and patterned, or alternatively institutionalized, not because it is imposed, but because it is elicited.

But there is a wish to "blend rational choice analysis and narration". Thus, "Our approach is narrative; it pays close attention to stories, accounts, and context. It is analytic in that it extracts explicit and formal lines of reasoning, which facilitates both exposition and explanation", p. 10. It also "focuses on choices and decisions", p. 13. But the narrative plays no analytical role, simply serving to determine which model or game should be considered to be appropriate and which equilibrium results. This is hardly a recipe for studying change, let alone endowing it with a genuine historical and developmental content.

\section{$4 \underline{\text { Twixt Development Economics and Studies }}$}

To a large extent, the previous account is deeply rooted within the evolution of development economics to what should be its familiar current state and prospects. But the view from outside the field or from within development studies is very different but equally subject to change both on its own terms and in relationship to development economics. First and foremost, development studies has increasingly drawn upon, indeed has been formed out of, the study of development within disciplines as in the geography of development, the sociology of development, and so on. In this respect, it incorporates a range of methods and methodologies far wider than, and generally in opposition to, those offered by mainstream economics. Not surprisingly, the division between development studies and economics has tended to mirror the differences or hostile relations between the other social sciences and 
economics more generally around the validity or otherwise of methodological individualism of a special type and reliance upon more or less sophisticated statistical regressions.

Second, this multidisciplinarity has provided the opportunity and motivation for, and often the actuality of, interdisciplinary study. Third, the range of topics studied is far, far broader than those that come under the rubric of development economics (although open to economics imperialism). Fourth, greater reliance upon inductive use of case study evidence (as opposed to statistical manipulation of large data sets) has meant that development studies has placed much greater emphasis upon specificity, context and meaning as opposed to ignoring these or taking them as unproblematic. This has, in the extremes of postmodernism, allowed critical theory to be exclusively concerned with the deconstruction of the meaning of concepts as opposed to attaching the generation of those meanings to (the study of) material practices themselves. This has to some extent conceded the terrain around analysis of material practices (including policy) to those who are entirely without critical sensibilities in the postmodern and, often, any other sense. But this is not inevitable, universal nor, I would suggest, unchallenged, and the balance across these issues is shifting unevenly and variously across the social sciences. Indeed, whilst the rush from one post-ism to another continues to prevail, the increasing significance of attempts to come to grips with the material and the critical is one of the most marked and encouraging intellectual developments around the turn of the millennium. Fifth, the presence of critical scholarship within the constituent disciplines of development studies, and within development studies itself, has been married to a more aggressive motivation around the object of study, ranging from the wish to do good (or better) through to systemic critique. Of course, these are not absent in development economics but they are of a much lesser degree of depth and breadth, almost inevitably as a result of the method and substance of what is involved. To put it polemically, if you were genuinely concerned about development and the poor (or the economic more generally), the last thing you would study is economics. There is, to use the vernacular, sample selection bias in who studies what and with what results, with radical and critical scholarship being attracted away from economics.

Before pursuing these points further across the evolution of development studies (in relation to development economics), two further general remarks are helpful. The first concerns interdisciplinarity and a general presumption that this places a discipline or field such as development studies at a disadvantage in light of what is presumed to be parasitic dependence and dilution. This is not my own experience, certainly as an inevitability, and outcomes are much more complex and mixed, accidental even, to be reduced to such simple prognostications. Consumption studies, for example, over the past few decades has long been at the forefront of critical theory, but this did not prevent it from being unduly captured by the extremes of postmodernist interpretative discourse at the expense of what is now a much more promising attention to the material culture of consumption. ${ }^{6}$

Management studies, on the other hand, might be seen to be the most selfserving and shallow of disciplines, dictated to by powerful corporate interests and vocational motivation. Yet, in the UK, the organisation of Critical Management Studies is reputed to include one-third of all academics, had its origins in Marxist labour process theory, and displays a bewildering array of the most advanced and 
trendy methods and topics. This reflects the peculiarities of the timing and mode of forming management studies in the UK but it demonstrates the extent to which the strength of critical scholarship is not confined by multidisciplinarity even in the most unlikely fields (although I am mindful of the extent to which "distance", intellectual and/or geographical, from the United States is a significant factor in both of these examples, and the same applies to development studies).

Second, then, possibly uncontroversially, the evolution of a discipline needs to be placed in a broader context than in its own inner development as is brought out, even if in an extremely limited way, by Kuhn's notion of paradigm as being attached to a community of scientists which might be broadened to encompass practitioners in the widest sense. In this light, especially for development studies, it makes sense to distinguish the role played by scholarship as such from those attached to rhetoric, ideology or advocacy, and policy in practice. The relationship between these is not necessarily one of consistency although there are connections between them, and they also shift over time and across topic. Further, rhetoric, scholarship and policy in practice are also attached to the issue of realism across all three - whether and how and which evidence is used. Thus, at the grand level, neo-liberalism as rhetoric has been about leaving things to the market; in scholarship it has ranged from neoclassical monetarism to the mutually inconsistent neo-Austrianism; and, in practice, it has always been about heavy state intervention to promote private capital in general and finance in particular. By the same token, if overgeneralising, the shift in scholarship and rhetoric from Washington to Post Washington Consensus has to a large extent been accompanied by a hardening of the traditional Washington Consensus interventions. ${ }^{7}$

Now consider the rise of development studies in the period of the preWashington Consensus. The contribution set by the old development economics offered both a standard for the prevailing orthodoxy and what was primarily a critical scholarship on systemic grounds as point of departure. Development studies was heavily influenced by the political economy of development, not least with varieties of dependency or world system theory to the fore, raising systemic concern over the causes of lack of development as well as, or even in place of, how to bring it about. By the same token, such political economy was significant at the very least in providing a backdrop to the study of non-economic issues in development, with modernisation as a potential critical point of departure in ranging across the social sciences. In retrospect, the location of the study of development outside of economics, especially in the United States other than in the hands of applied or heterodox economists or economic historians, is a telling factor in the evolution of development studies in the pre-Washington Consensus period.

The contrast with the Washington Consensus and subsequently is striking. First and foremost, and both characteristic and causal, has been the emergence of the new (and newer) development economics, the application of economics imperialism to development where previously the influence of orthodoxy was at most reflected in a predilection for formal methods, whether mathematical models or the search for empirical regularities that could be attached to development.

Second has been the decline of the political economy of development through a pincer movement that has in general, if not universally, pushed it towards the 
margins. For the rise of the new development economics was promoted and accompanied by an increasing intolerance within the discipline to any heterodoxy, whilst development economics became less of a separate field and more of an application, like most other fields, of pervasive and uncritically deployed methods and principles. By the same token, the decline of heterodox political economy robbed the other social sciences of core critical economic content. This itself dovetailed with the rise of postmodernism, general hostility to (economic) reductionism, and emphasis on the discursive and its deconstruction at the expense of material realities. There was, in a sense, a conspiracy to fill out the analytical space through an extraordinary alliance around two totally incompatible approaches to subjectivity - that of neoclassical economics that was fixed within the individual and in meaning (utility of given goods) as opposed to the interpretative capacities and relativism of the knowing, feeling and inventive agent.

Third, whilst it is totally inappropriate to look back nostalgically upon an unblemished golden age of the pre-Washington Consensus for which the following factors cannot be presumed to be absent, donor agencies, the international financial institutions, and especially the World Bank, have now become increasingly dominant in setting the agenda for development studies, if less so than for development economics, and have themselves increasingly set the orthodoxy from which critical dissent takes its points of departure. This might be seen as the form taken by, or the surrogate for, Americanisation of development studies as a discipline given its formal absence as a discipline in the United States, with pride of place being occupied by mainstream economics across the disciplines. Further, this has not simply been a matter of influencing or determining intellectual boundaries, weight and momentum, but has also been accompanied by the dull compulsion of incentives around publish or perish, policy considerations, consultancies and research grants.

And the compelling motivational counterpart to such factors has been an increasing focus upon policy - or, more exactly, economic and social engineering as the goal of development studies in addressing everything from poverty to governance. This places critical scholarship, one that seeks to understand before, or in place of, intervening in a dilemma if the oppositional extreme of descent into a purely discursive critique is to be avoided as opposed to offering materially and systemically grounded proposals for alternatives (that neither border on unrealistic demands nor idealise the popular, resistance or social movements as such). Interestingly, those technical "engineers" of development who acknowledge the political role of their interventions have necessarily found themselves isolated, not only from orthodoxy for its wishing not to raise such issues, but also from critics who wish to raise nothing else, Biggs (2008) for an interesting personal account. In other words, the World Bank has increased both its influence on the social science of development and the influence of such social science (and economics within it) on development thinking. This has been at the expense of practitioners on the ground, in the sense of those with technical expertise who deliver development policy, unless these be social scientists. Policy debate has increasingly been about ideas, the knowledge bank, as opposed to delivery.

Fourth, this has all been associated with the decline in interdisciplinarity in development studies, especially where interaction with the economic is concerned. The exception that proves the rule is where economics imperialism is involved. For 
this has had the effect of appropriating the economic within development economics as well as within development studies more generally. Where the other social sciences have found this unacceptable, the response has tended to be one of retreat into intradisciplinary concerns at the expense of the economic, especially under the influence of postmodernism.

Fifth, what might be an exaggerated description of development studies as an uneven scattering across disciplines and topics, albeit with occasional concentrated effort and focus driven by academic or other fashions, has had the further effect of creating more intensive divisions and dissonance across rhetoric, scholarship, policy and realism. The roots for this lie primarily within the World Bank where the incidence of inconsistencies are pervasive, mixed and shifting but, crucially, overlaid by an extraordinary expansion in its activities as researcher, trainer and proselytiser, quite apart from seeking to lead policymaking through leverage of its own loans and self-appointed role as knowledge bank. ${ }^{8}$ The consequence has been that in place of the amorphous but at least single notion of modernisation, there has been the proliferation of developmental terminology, from good governance through to corruption, each element of which has to be critically unpicked across rhetoric, etc, to make any sense of what is being said or, possibly more important, being done.

This is, however, to have moved past the Washington to the Post Washington Consensus. For the former, the rhetoric of leaving everything to the market responded to its own developmental failures, the missed decades, by explaining how this was the consequence of not adopting its policies in practice. For the PWC, it has been more of the same but with a more constructive gloss and state-friendly stance even if with preference for the market wherever possible. But, despite the foregoing, it is important not to overlook nor to dismiss the role played by dissent from the development studies community (as well as recognising the channels into which it was drawn).

In the 1980s, two main elements in such dissent were offered by notions of the developmental state and adjustment with a human face. These are indicative of the trends we have identified. The developmental state literature has been fragmented into two schools, the economic and the political, with one emphasising the need for policies to correct, or make, market imperfections, irrespective of the politics of implementation; the other examining the conditions under which the state is capable of acting developmentally without regard to the policies themselves. On this, a more than creditable critique was able to be launched on the Washington Consensus, not least in light of the East Asian NICs. But the developmental state literature was already in decline by the mid-1990s, prior to the Asian financial crises, and was considerably outflanked by the PWC that simply ignored it and pretended to have invented something similar in its own watered-down and piecemeal version, Fine (2007c).

Adjustment with a human face offered an equally commendable critical function along the lines of "it's hurting and it ain't working", at least for the poor across an increasingly wide range of diverse topics. Significantly, in parallel with such contributions, again analytically and critically diluted by PRSPs, MDGs and the like, has been the impact of the work of Amartya Sen, possibly the most prominent of interdisciplinary economists, certainly so for development. To a large extent, though, 
this has been the result of his considerable intellectual powers and energy. His contributions have been mainly confined to straddling the boundaries between economics and (moral) philosophy. Further, the passage from social choice theory through famine, entitlements, capabilities, through to freedom has been marked by some reliance upon the analytical framework of microeconomics (or at least tensions between the micro and the macro), a remarkable absence of causal content, and, despite his work on famine, a lack of engagement with the specific and contextual content of the separate elements that make up entitlements, capabilities and freedom (with the suspicion that the entitlement approach to food, however appropriate, has informed a broader application). The result has been to place, in practice if not in principle, limits on the extent and nature of interdisciplinarity and the depth and breadth of critique to be found in development studies arising out of Sen's work, Fine (2004b).

This has been especially so for the period of the PWC and corresponding Comprehensive Development Framework. Within a decade of its launch, albeit with continuing tensions, the PWC has made remarkable strides in reconstructing the relationship between scholarship, rhetoric, realism and policy in practice. It remains crucial not to overgeneralise and homogenise across different areas. But, for the scholarship, the newer development economics has been extraordinarily successful in opening up development to mainstream economics in six distinct but complementary and mutually supportive ways. First, it allows a much wider set of economic issues to be addressed as a consequence of explanation based on market imperfections. Second, it allows a much wider set of non-economic issues to be incorporated in light of appeal to imperfect institutions. Third, the application of these principles is not contingent upon any detailed knowledge of development, development studies, or particular countries or regions other than through access to readily available data sets. Fourth is the expansion of such data sets and the capacity to handle them. Fifth, the market/institutional imperfection approach is far more palatable to other social scientists than the neo-liberal alternative. And, sixth, research funding has been increasingly associated with the World Bank both as a source of support and legitimisation.

In case of rhetoric, and more in the purveying of knowledge and command of training of development professionals, the putative role of the World Bank as knowledge bank has been particularly prominent. It has, of course, been accompanied by a more state-friendly stance in principle in case potential correction of market and institutional failures can be demonstrated to be beneficial. But the underlying logic is one of promoting the market or globalisation. The extent to which this rests on a realistic assessment of the consequences involved, both in depth and breadth, is a matter of concern in light of burgeoning problems, the environment for example now increasingly sandwiched between limited progress on poverty (especially in Africa) and the threat of financial crises as the new kid on the block. And there is an equally cavalier attitude towards causation. Questions of power and conflict continue to be notable for their absence. As far as policy goes, there is little evidence to suggest that there has been a great deal of movement in practice from the core practices of the Washington Consensus, even if there is now a rationale for piece-meal and discretionary intervention on a wider scale where before such a rationale was denied in principle if not in practice, Fine et al (eds) (2001), Jomo and Fine (eds) (2006) and van Waeyenberge (2007). 


\section{Future Prospects}

This is to paint a very depressing picture of the extent to which development studies has been influenced by, if not succumbed to, zombieconomics. But it is neither a full nor, thereby, a balanced picture of the current state of play and prospects. For, there are a number of decisive positive features within development studies. First is its genuine multi-disciplinarity and, on occasion, interdisciplinarity. This means that development studies is irreducibly attached to methods, issues, theories and concepts that zombieconomics is incapable of appropriating and/or dominating. Thus, the fate of development studies does not lie in the hands of (development) economics but is dependent upon developments within other disciplines and how they impact upon the way in which they engage with, and contribute to, development studies whether deliberately or otherwise (just as the various phases of economics imperialism have affected development economics without that initiating intention).

Second, again over generalising, there has been, across the social sciences other than economics, a dual retreat from the extremes of both neo-liberalism and postmodernism as analytical agenda-setting devices. This is apparent in the equally general, if not universal, interest in addressing the material realities of contemporary capitalism. What is the world in which we live? Significantly, the most important concept bearing on this issue to emerge over the last twenty years (and no longer than this) is globalisation. Crucially, it has been won away from its neo-liberal project (the state is withering away and this is a good thing) and is now attached to a bewildering array of studies appealing both to the systemic operation of capitalism on a world scale and, yet, demonstrating the continuing salience of the nation-state, its interventions and the importance of specificity, Fine (2004a). Inevitably, such developments have engendered both a renewal of interest in political economy and, to a greater or lesser degree, an antipathy to economics imperialism both within development studies and more widely.

The result is that within each discipline, and across topics, the outcome is uncertain depending upon how the intersection of the conflicting intellectual trends identified is handled. The same applies to development studies and interdisciplinarity more generally. In this, the post Washington Consensus has very little to offer analytically, and in other respects, as a result of its methodological individualism seeking, as already indicated, to pick its way simplistically between the potential benefits of globalisation and its admitted downsides. But, for all his high profile on the issue, as representative of the post Washington Consensus, Stiglitz has had very little substantive to say about the systemic nature of globalisation or, indeed, about it at all. When confronting himself with the issue of why his advice and reasoning have been set aside by both the US government under Clinton and the World Bank when he was Chief Economist, he concludes it is due to the ideology and vested interests of finance. As argued elsewhere, this suggests these elements should be taken as starting point for continuing analysis, Fine (2007b). On the other hand, in case of social capital for example, as I have argued extensively, there has been an extraordinary degradation of social science as this concept has exploded in scope of application. And, as far as the World Bank and development studies are concerned, this has been particularly unfortunate in being at least complicit with economics imperialism, 
overlooking the systemic, and often proceeding as if globalisation, class, power, meaning and conflict had never been heard of, Fine (2003, 2007a, 2008b and c).

Third, though, account must also be taken of the material circumstances under which development studies will evolve in the coming period. Although this is generally understood in terms of globalisation and neo-liberalism, variously interpreted, the defining characteristic of the current period is one of financialisation, Fine (2007b). It is not simply that there has been a growth and proliferation of financial services, but these have penetrated into, and mediate, an ever-increasing array of our economic and social lives. Financialisation is both in the vanguard and the beneficiary of privatisation, commercialisation, liberalisation, commodification, and so on. This is not to say that financialisation is either all-powerful or homogeneous in its effects. Quite the opposite which is why, for example, there should be a renewal of interest in Polanyi's double movement, not least as the financial and other crises of the last decade or more seemingly threaten the well-being of developed as well as developing worlds.

This also suggests that, crudely overgeneralising, neo-liberalism should be understood as having entered a second phase. The first is appropriately understood in terms of shock therapy, particularly for those developing countries undergoing adjustment under the Washington Consensus, and not to be confined to the transition economies of eastern Europe. For the intent was to release market forces, or private capital in general, as much as possible, and finance in particular. This first phase has now run its course and is giving way to a second phase with two closely related elements. One is to temper the worst excesses of the first phase, thereby presenting itself as more state-friendly and humane, the social market but the market nonetheless. The other is for the state to intervene to allow for the continued progress of financialisation. This is transparent for those who care to see in case of the extraordinary interventions that are being used to prop up the financial system, not least with huge subsidies from the state - whilst those who have suffered the damage, as home-owners for example, must pay the price. But also, for example, as privatisation has begun to falter, especially in the (poorest parts of the) developing world as is recognised by a World Bank apologetic for its previous dogma on the issue, so policy becomes a matter of the state supporting the private sector to deliver rather than conceding to it. The same is true of public services more generally as the era of user costs and subsidy elimination has given way to a stance of public-private partnerships, Bayliss and Fine (eds) (2008).

The analytical and policy dilemmas posed for development studies by this situation is beautifully if inadvertently and implicitly anticipated by Sir Josiah Stamp. Apart from serving on the Board of the Bank of England, he was reputedly the second richest man in the UK in the 1930s as a result of his financial and other interests: ${ }^{9}$

Banking was conceived in iniquity and was born in sin. The bankers own the earth. Take it away from them, but leave them the power to create money, and with the flick of the pen they will create enough deposits to buy it back again. However, take it away from them, and all the great fortunes like mine will disappear and they ought to disappear, for this would be a happier and better world to live in. But, if you wish to remain the slaves of bankers and pay the cost of your own slavery, let them continue to create money. 
A moment's reflection will reveal the striking affinity between this judgement and dependency theory - once replacing notions of core-periphery with those associated with banking versus the rest. There is not only the moral opprobrium associated with surplus (wealth) transfer but also the presumption of a mechanism by which such transfers are realised (dependency of some sort as opposed to the flick of the pen) and irrespective of efforts to the contrary unless they run very deep (sufficient detachment from the world system or abolition of right to create money).

It is not my intention to dwell here upon the strengths and weaknesses of dependency or world system theory but only to bear them in mind as we interrogate Stamp's posture. For an example of the parallel, see Biel (2000). The promise of utilising finance is mirrored in the idea that, "NICs do at least represent some real change", p. 190, so that, "some parts of the South could take advantage of weaknesses in the North's control mechanisms and gain some degree of real autonomy", p. 191. And, for taking it all back again, "the colonies were fashioned in such a way that they would permanently service the accumulation needs of the fully capitalist economies", p. 12. Thus, "import substitution did have a flaw from capitalism's point of view ... if consumption of the product was local, wages would eventually have to rise to provide additional demand, and this would eventually contradict the whole assumption upon which internationalisation occurred, namely cheap labour. The development potential of the model was thus limited; it would work for a while, but then would have to be scrapped. And this is exactly what happened. At the end of the 1970s, the dominant forces in the world economy turned against import substitution as vigorously as they had once propagated it", p. 81/2. But, whether for finance or underdevelopment, despite its power as metaphor on its own terms and as a starting point for investigative purposes, there are more questions raised than answered. First of all, for finance at least, the metaphor refers exclusively to the redistribution of wealth. Even so, what are the mechanisms by which wealth is retrieved through the capacity to create money? What are the implications for the nature and rate of accumulation, and the levels and distribution of employment and/or rewards amongst those outside the banking system? And what is the broader impact on social and economic reproduction?

On these issues, Stamp's stance is simply one of silence but they are decisive for the fate of development studies, and its constituent disciplines, in the coming period. For if, as suggested, financialisation is the defining systemic feature of the current period, then explicitly or implicitly by default, some stance must be taken on the role of finance in whatever is being addressed. This is obviously so for systemic study itself, not least with financial crises on the horizon, the rise of China, the increasing indebtedness of the United States, and so on. But Stamp, suitably refined and qualified, offers an investigative edge in the study of environmental controls for example. Is this to be another opportunity for financialisation with the bizarre prospect of burgeoning future trading in not producing something? To understand how such fetishised markets could arise with what effects, what they are and what they mean surely depends upon a political economy of capitalism and of finance that draws upon an interdisciplinarity in which development studies could and should be in the lead. 
This is especially important for policy purposes, and the analytical frameworks that inform policy. The sub-prime mortgage crisis has revealed not only how vulnerable is the global financial system in its proliferation and extension of interacting markets but how support for these in crisis commands government intervention and resources at the expense of those activities that finance is putatively deemed to support. To be parochial and polemical, would not the Bank of England's rescue of Northern Rock have been better spent in funding the building of tens of thousands of homes directly? But what is true of housing and those previously dependent upon the sub-prime market is of much wider and general relevance to all other aspects of economic and social reproduction throughout the world of development and development studies. It is important both to emphasise the heterogeneous if pervasive impact of financialisation and the variety of mechanisms through which its incidence is felt, as well as the need to anaesthetise or isolate progressive interventions from its global reach.

What role can political economy play within development studies as the latter addresses the second phase of neo-liberal financialisation? The prior question is the nature of the political economy to be deployed itself. This requires a judicious mix of both abstract theory and contingent context, with characterisation of the current period of contemporary capitalism combining both. Consider, for example, the work of Bob Brenner. The first Brenner debate on the transition from feudalism to capitalism centred on the significance of class conflict, and the relative importance of production as opposed to exchange, following the earlier Dobb-Sweezy debate. As such, the debate has had immediate implications for development understood in part in terms of how capitalist relations of production are established. The second Brenner debate is removed from such considerations in a number of ways. Brenner does not deal with development even indirectly since his pre-occupation is with a tri-partheid competitive conflict between US, Japanese and European (predominantly German) blocs of capital. This is in itself questionable given the internationalisation of capitalist production (and inter-affiliate trade) of multinational corporations. But Brenner does usefully point to the error of posing working class militancy and advance (for money and social wage) as the source of the malaise (slower growth, investment and productivity increase) in the capitalist world over the past thirty years in contrast to its performance over the post-war boom (when living standards were, of course, rising rapidly). For both militancy and rewards to labour have at most been limited.

In rejecting class struggle between capital and labour as the immediate cause of the slowdown in contemporary capitalism, Brenner switches attention to intra-class conflict, between capitalists, as the decisive factor. In particular, he argues that incumbent large-scale capitals have occupied existing market demand and deterred new entrants and investment, including their own. The implication, if not drawn by Brenner himself, is that developing economies will be constrained as much if not more by such incumbents. This is all, however, fraught with both theoretical and empirical weaknesses. Theoretically, it views the restructuring (and expansion) of capital as contingent upon a simple process either of self-expansion within an individual sector or entry by new investment from another. But the restructuring of capital is levered by other mechanisms as well, not least acquisition and mergers as well as through state intervention (to the point of nationalisation during and/or underpinning the post-war boom). At an empirical level, Brenner would presumably 
have difficulty explaining the success of the East Asian NICs, as well as the extraordinary success of China that has shot to prominence since his investment overhang hypothesis was first put forward. Of course, as with Biel, this can be dismissed, or embraced, as exceptional. But as argued by Fine et al (2005), Brenner's account is also shown to be wanting when shifting from (developing) country to sectoral level. For the steel industry, whilst exceptionally favourable to Brenner in principle in view of its heavy levels of fixed investment and thereby conducive to incumbents, has experienced extensive changes in technology, location of production, sourcing of markets, and emergence of new entrants.

As a result, if only by way of omission, Brenner has usefully pointed to the significance of the levers for the restructuring of capital as underpinning the slowdown of accumulation. As already observed, these depend not only upon intraclass relations between the productive capitals directly engaged but also upon the financial system and the state as agens of restructuring. The impact, indeed the nature, of neo-liberalism has been for financialisation to have substituted the expansion of and extension of financial markets at the expense of industrial restructuring. Moreover, the thrust of neo-liberalism has also been to constrain state restructuring of industry in deference to financial interests as well as at the expense of the more general role that the state can play in furnishing the economic and social provision that supports growth and development.

In these respects, David Harvey's work is more penetrating, especially Harvey (2003 and 2005). Rooted in a continuing commitment to Marxist political economy, he has in particular attached the fate of development to the notion of primitive accumulation extending it by use of the term "accumulation by dispossession". This is the means by which to address a wide range of phenomena from plunder through to privatisation of public services. In addition, he has posited the notion of a "fix", especially a spatial fix, as a way of mediating between abstract theory and concrete developments (the geography of underdevelopment, for example) as accumulation proceeds.

As argued elsewhere, Fine (2006), there is no need to confine ourselves to spatial fix or otherwise. Presumably, there are also gender, labour, class, race, environmental, cultural and any other number of fixes as the preconditions for, and consequences of, continuing accumulation. To the extent that emphasis is placed upon one or another, this presumably reflects either the object of study or the judgement of what is of more general significance in the current conjuncture. Further, the idea that accumulation by dispossession, especially out of the non-capitalist world, is what sustains capitalism is open to an inverted interpretation. Capital accumulation is not dependent on accumulation by dispossession but the latter is liable to be intensified when accumulation through its own inner momentum is constrained. Such is the nature of the contemporary financial fix in which the surplus available to reward and to sustain financialisation is limited by the slower pace of real accumulation induced. Financialisation both reduces the surplus produced and appropriates more of it, inducing accumulation by dispossession as a reaction. Otherwise, Harvey's accumulation by dispossession would appear to be a generalisation of Luxemburg's discredited underconsumptionism as an explanation for imperialism in which the need for non-capitalist markets is perceived to be essential for capitalism. This is not to deny that accumulation by dispossession is both important and inevitable for 
contemporary capitalism, only that its significance cannot be derived as a sine qua non of capital accumulation.

More constructively, the following can be posed as essential to a political economy of capitalism with corresponding implications for the role it can play within development studies, drawing on Fine (2004a). First is to incorporate an appropriate value theory, one which addresses issues of class, power and conflict in the context of capital accumulation. Marx's value theory has been subject to intense conflict, of interpretation as well as of legitimacy. Paradoxically, the reasons put forward for rejecting Marx's value theory - ranging over technical and quantitative issues of the relationship between value and price through to the more developed forms taken by capitalism such as monopolisation and, most recently, new technology - are precisely the same as those for remaining committed to it, Fine (2003b). This paradox is resolved once it is recognised that Marx's value theory is concerned to identify how the way in which production is organised is attached both qualitatively and quantitatively through all other relations in capitalist society, with the commodity form as central alongside the creation and appropriation of surplus.

Second, attention necessarily focuses on the relationship between classes and the state and how they resolve and sustain the conflicts associated with a system of accumulation? Third, as already emphasised, what is the relationship between the financial and industrial systems in the process of accumulation? Fourth, what are national differences in systems of accumulation, and how are they to be indentified and related to (fractions of) classes and their conflicts and reproduction? Fifth, why are sustained periods of economic growth punctuated by crises? Sixth, what is the relationship between economic and political systems and how can they be addressed by a genuinely interdisciplinary approach? Seventh, what is the relationship between economic and cultural factors? And, eighth, how do the new world order, US hegemony, and the factors associated with "globalisation" impact upon the prospects for growth and development?

\section{Lessons from South Africa in Lieu of Conclusion ${ }^{10}$}

Whilst each of these issues could be addressed at considerable length, I am acutely conscious of how abstract and theoretical insights also need to be grounded in the diversity and multiplicity of determinants in specific instances. Take the case of South Africa, for example. As argued elsewhere, especially Fine and Rustomjee (1997), the South African economy can be characterised as being dominated by a minerals-energy complex, MEC. What is meant by this? Although controversial as an approach and otherwise considered confined to a more or less distant past, the MEC is understood as an integral partnership between state and private capital, and an equally integral connection between a core set of activities around mining and energy, straddling the public/private divide. It offers a way of capturing the distinct nature of the South African system of capital accumulation in terms of its structures, relations, agents and processes.

In the interwar and immediate post-war period, core MEC sectors drove the economy, furnishing a surplus for the protection and growth and, ultimately, incorporation of what was initially small-scale Afrikaner capital separate from the core sectors. State corporations in electricity, steel, transport and so on, represented an accommodation across the economic power of the mining conglomerates and the 
political power of the Afrikaners. Mining capital required corresponding inputs but was reluctant to invest the necessary funds in case of hostile appropriation by Afrikaner interests which were, nonetheless, served by the revenue that could be extracted from the MEC albeit at the expense of provision of state corporations primarily serving mining and related sectors. The apartheid labour systems, involving migration from the southern African region to mining, and varying degrees of segregation within the country, were less an accommodation than a common bond.

As a result, the divisions between Afrikaner and mining capitals precluded a more general strategy of industrial diversification out of core MEC sectors, leading to a partial vacuum in intermediate and capital goods capability, a failure to accrue economies of scale and scope other than in core MEC sectors, and an inefficient consumer goods industry surviving by protection upon demand. By the 1970s, though, Afrikaner and mining-related capital had been sufficiently integrated for a common economic strategy to be adopted, as had always been the case for labour systems. But, with the collapse of the post-war boom and the Bretton Woods system based on gold at $\$ 35$ per ounce, and the sharp rise in oil and energy prices, a huge premium attached to both gold and energy. Consequently, an industrial strategy for diversification was scarcely considered let alone adopted. Instead, the 1970s witnessed an extraordinary state-led expansion of gold and energy production. Into the 1980s, the crisis of apartheid also precluded a state and/or private strategy for industrial promotion. But, whilst the core MEC industries remained central to the economy, capital controls meant that profits generated internally that were not illegally transferred abroad, were confined to accumulation within the South African economy itself. This gave rise both to intensified conglomeration across the economy but, first and foremost, to the expansion of a huge and sophisticated financial system as cause and consequence of the internationally confined, but domestically spread, reach of the South African conglomerates with the Anglo-American Corporation in the lead.

But what has happened to the MEC since the demise of apartheid? The interests of conglomerate capital have not been galvanised by the state for internal developmental purposes. On the contrary, conglomerates have successfully pressed for their own strategy of corporate globalisation and financialisation and, first and foremost, for the export of their domestic resources and control. This has governed the role played by the state in its macroeconomic policy, with policies more or less indistinguishable from those of orthodox IMF stabilisation being adopted to allow liberalisation of capital flows on favourable terms. It has also constrained the resources for, and commitment to, industrial as well as social and economic infrastructural development.

In short, over the post-apartheid period, the economy has primarily been driven by allowing for the financialisation and export of domestic conglomerate capital, whilst continuing to draw upon the surplus that can be derived from core and related MEC sectors. This is all stunningly indicated by the rapid growth of the financial sector itself. It now accounts for one-fifth of domestic income but has continued to fail to mobilise and prompt appropriate funding for domestic investment, with forty percent of the population being without direct access to financial services at all. Far from finance serving development, the effect has been for it to absorb onefourth of what is produced with very little in return other than in speculative and globalised profitability. 
From this highly abbreviated account a number of broader lessons can be drawn. First, value theory does allow finance to be seen other than simply as some other sector of the economy (as services), and the nature of those services in contemporary capitalism are fixed both in general and in the context of South Africa. But financialisation continues to depend upon the surplus that the economy can generate. It cannot float free from production, and this helps to explain what appears to be a renewal of commitment by the state in South Africa over the last few years to promote production around core MEC sectors.

Second, the corresponding consequences for traditional and new concerns within development studies are conditioned by, but not reduced to, this dynamic. We witness, for example, the emergence of a new black elite through Black Economic Empowerment (BEE) or, more exactly, Black Elite Economic Enrichment, BEEE, around finance. This has been achieved primarily through the gains spun off through financial restructuring. It represents a (fraction of a) class in the making, one that is entirely dysfunctional and parasitical for development. By the same token, commitment to poverty alleviation whether through employment creation, industrial policy, or social provision is heavily constrained by the subordination of policy to financial imperatives. This is true not only of financial resources but also of the ideology of delivery and the lack of effort placed on creating the institutional capacity to deliver. This is not to reduce all that happens to the economics and corresponding vested interests attached to the MEC and its continuing evolution. Rather, whilst this does explain much of the thrust of developments and policy in terms of both direct and indirect effects, it also provides the context within which other policies are constrained, not least through the politics of subordinating the process of policy making to the hegemony of the Ministry of Finance.

Finally, this is all far from signalling the end of class and of production as decisive moments in contemporary capitalism as is variously argued by some, within development studies or otherwise, in variously pointing to the cultural, the new social movements, the new economy, and so on. Rather, as is most sharply evidenced by financial crises, how they are resolved (and who bears the burden), capitalism and development are grounded in systems of production. Across issues that remain the bread and butter for development studies - as diverse as poverty, governance, corruption, developmental state, protest, conflict, empowerment, and so on, let alone globalisation, neo-liberalism and social capital - the challenge remains to ground, possibly reject, these notions critically in material practices and corresponding analyses in which political economy plays an essential role.

\section{$\underline{\text { Footnotes }}$}

${ }^{1}$ For an account of economics imperialism, see Fine and Milonakis (2009). 
${ }^{2}$ See also Rostow's (1957, p. 510) stated preference for interdisciplinarity "because I was repelled by Marx's economic determinism".

${ }^{3}$ Rodrik's second principle is to sift the empirical evidence, his third is to have some faith in government, his fourth is to be context specific, his fifth is to prioritise, and his sixth is to be modest. My own experience of the Harvard team's application of this approach to South Africa, with Rodrik as participant, is that most of these principles are observed in the breach other than the first to which should be added a seventh as engage in speculative and idiosyncratic reasoning, and an eighth ignore legitimising role, http://www.cid.harvard.edu/cidwp/161.html and Fine (2008g) for critique.

${ }^{4}$ See also Agénor and Montiel (1996, pp. 11-12) for whom:

We do not believe that economic agents in developing countries behave differently from those in industrial economies, in ways that are inconsistent with the rational optimising principle of neoclassical microeconomics; rather, we believe that they behave similarly to their industrial counterparts, but operate in a different environment.

But, despite insisting that development economics requires the same analytical principle of the rational optimising individual, this principle is deemed not only to reproduce but also even to advance the cause of structuralism. For, "Many of the areas in which 'orthodox' thinking has provided much insight (has) ... ironically, even strengthened new structuralist arguments", p. 3. It is crucial to recognise that such structuralist arguments (and development economics and studies more generally) are being appropriated and reinterpreted within a mainstream neoclassical microeconomic framework.

${ }^{5}$ It is significant that the efforts of Krugman and others in this vein tend to be lauded within regional science as a discipline as opposed to (more rounded and interpretative) economic and human geography itself, a significant illustration of the diverse outcomes within and across disciplines associated with economics imperialism (and of enormous importance for the prospects of development studies). ${ }^{6}$ Significantly, more traditional studies of consumption, rooted in marketing studies, retained strong links, however conceptually impoverished, with the material in light of the study of the need to sell something.

${ }^{7}$ See especially van Waeyenberge (2007)

${ }^{8}$ See especially van Waeyenberge (2007).

${ }^{9}$ See http://en.wikipedia.org/wiki/Josiah_Stamp,_1st_Baron_Stamp

${ }^{10}$ The following draws upon and considerably abbreviates discussion in Fine (2008df). 


\section{$\underline{\text { References }}$}

Agénor, P. and P. Montiel (1996) Development Macroeconomics, Princeton:

Princeton University Press.

Bates, R. et al (1998) Analytic Narratives, Princeton: Princeton University Press.

Bayliss, K. and B. Fine (eds) (2008) Whither the Privatisation Experiment?:

Electricity and Water Sector Reform in Sub-Saharan Africa, Basingstoke: Palgrave

MacMillan.

Biel, R. (2000) The New Imperialism: Crisis and Contradictions in North-South

Relations, London: Zed Books.

Biggs, S. (2008) "The Lost 1990s?: Personal Reflections on a History of Participatory

Technology Development", Development in Practice, vol 18, no 4\&5, forthcoming.

Fine, B. (2003a) "Social Capital: The World Bank's Fungible Friend", Journal of

Agrarian Change, vol 3, no 4, pp. 586-603.

Fine, B. (2003b) "Value Theory and the Study of Contemporary Capitalism: A

Continuing Commitment", in Westra and Zuege (eds) (2003).

Fine, B. (2004a) "Examining the Idea of Globalisation and Development Critically:

What Role for Political Economy?", New Political Economy, vol 9, no 2, pp. 213-31.

Fine, B. (2004b) "Economics and Ethics: Amartya Sen as Point of Departure",

ABCDE Conference, Oslo, June, 2002, published in The New School Economic

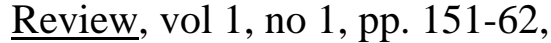

http://www.newschool.edu/gf/nser/articles/0101_fineb_econandethicssen_fall04_final .pdf

Fine, B. (2006) "Debating the 'New' Imperialism", Historical Materialism, 2006, vol 14, no 4, pp. 133-56.

Fine, B. (2007a) "Social Capital", Development in Practice, vol 17, no 4 \& 5, pp. 566574.

Fine, B. (2007b) "Financialisation, Poverty, and Marxist Political Economy", Poverty and Capital Conference, 2-4 July 2007, University of Manchester.

Fine, B. (2007c) "State, Development and Inequality: The Curious Incidence of the

Developmental State in the Night-Time", paper presented at Sanpad Conference,

Durban, June 26-30.

Fine, B. (2008a) "Zombieconomics: The Living Death of the Dismal Science in the Age of Neo-Liberalism”, paper for ESRC Neoliberalism Seminar, 1st April 2008, http://www.cppr.ac.uk/centres/cppr/esrcneoliberalismseminar/

Fine, B. (2008b) "Social Capital and Health: The World Bank through the Looking Glass after Deaton", mimeo.

Fine, B. (2008c) "Social Capital in Wonderland: The World Bank behind the Looking Glass", Progress in Development Studies, forthcoming.

Fine, B. (2008d) "Engaging the MEC: Or a Lot of My Views on a Lot of Things", paper for MEC workshop at University of KwaZulu-Natal, Durban, June.

Fine, B. (2008e) "Can South Africa Be a Developmental State?", paper presented to HSRC workshop, Pretoria, June.

Fine, B. (2008f) "The Minerals-Energy Complex is Dead: Long Live the MEC?", Amandla Colloquium,

http://www.amandlapublishers.co.za/component/option,com_docman/task,cat_view/g id,100/Itemid,163/

Fine, B. (2008g) "Review of "The Final Recommendations of the International Panel on Growth' (the Harvard Panel)", Submission to the COSATU Panel of Economists, June. 
Fine, B. and D. Milonakis (2009) From Economics Imperialism to Freakonomics: The Shifting Boundaries Between Economics and Other Social Sciences, London:

Routledge, forthcoming.

Fine, B. and Z. Rustomjee (1997) South Africa's Political Economy: From MineralsEnergy Complex to Industrialisation, Johannesburg: Wits University Press.

Fine, B. et al (2005) "Beyond Brenner's Investment Overhang Hypothesis: The Case of the Steel Industry", New Political Economy, vol 10, no 1, pp. 43- 64.

Fine, B. et al (eds) (2001) Development Policy in the Twenty-First Century: Beyond the Post-Washington Consensus, London: Routledge.

Harvey, D. (2003) The New Imperialism, Oxford: Oxford University Press.

Harvey, D. (2005) A Brief History of Neoliberalism, Oxford: Oxford University

Press.

Huff, W. et al (2001) "Credibility and Reputation Building in the Developmental

State: A Model with East Asian Applications", World Development, vol 29, no 4, pp. 711-24.

Jomo, K. and B. Fine (eds) (2006) The New Development Economics: After the

Washington Consensus, Delhi: Tulika, and London: Zed Press.

Krugman, P. (1992) "Toward a Counter-Counterrevolution in Development Theory", World Bank Economic Review, Supplement, (Proceedings of the Annual Bank

Conference on Development Economics), pp. 15-39.

Kuznets, S. (1971) Economic Growth of Nations: Total Output and Production

Structure, Cambridge: Harvard University Press.

Rodrik, D. (2007) One Economics, Many Recipes, Princeton: Princeton University

Press.

Rostow, W. (1957) "The Interrelation of Theory and Economic History”, Journal of

Economic History, vol XVII, no 4, pp. 509-23.

Rostow, W. (1991) Stages of Economic Growth: A Non-Communist Manifesto,

Cambridge: Cambridge University Press.

Toye, J. (1993) Dilemmas of Development, Oxford: Blackwell.

Van Waeyenberge, E. (2007) Exploring the Emergence of a New Aid Regime:

Selectivity, Knowledge and the World Bank, PhD thesis, University of London.

Westra, R. and A. Zuege (eds) Value and the World Economy Today, London:

MacMillan. 